\title{
Land in the Political Economy of African Development: Alternative Strategies for Reform
}

\author{
Sam Moyo*
}

\begin{abstract}
Since 2000, there has been an escalation of land-related conflicts in Zimbabwe, Côte d'Ivoire, the Delta region of Nigeria and elsewhere in Africa. These conflicts are examples of numerous national struggles for access to land in Africa and reflect the failure of the African state to address the land and development nexus on the continent. The land question in Africa is a by-product of globalised control of land, natural resources and minerals in general, reflecting incomplete decolonisation processes in ex-settler colonies along with the penchant for foreign 'investment' in a neo-liberal policy framework that marginalises the rural and urban poor. Global finance capital is increasingly entangled in conflicts over land, as the exploitation of oil, minerals and natural resources expands into new African enclaves that highlight the external dimension of distorted development. These processes define the significance of land in the political economy of African development. This paper examines the complex social and political contradictions that shape land struggles, including their colonial and post-independence trajectory. The failures of neo-liberal land reforms, based on market forces and their confrontation by popular demands for redistributive reforms are discussed.
\end{abstract}

\section{Résumé}

Depuis l'an 2000, il y a eu une escalade de conflits liés à la terre au Zimbabwe, en Côte d'Ivoire, dans la région du Delta au Nigeria et ailleurs en Afrique. Ces conflits sont des exemples des nombreuses luttes pour l'accès à la terre en Afrique, et reflètent l'incapacité de l'Etat Africain à aborder le lien entre terre et développement sur le continent. La question foncière en Afrique est un sousproduit du contrôle planétaire de la terre, des ressources naturelles et minières

* Prof Sam Moyo is at the African Institute for Agrarian Studies (AIAS), 19 Bodle Avenue, Eastlea, Harare, Zimbabwe. Email: sammoyo@ecoweb.co.zw 
en général, qui reflète le processus incomplet de décolonisation dans les anciennes colonies de peuplement de même que l'inclination en faveur de « l'investissement » étranger dans un cadre de politique néo-libérale qui marginalise les pauvres des zones rurales et urbaines. Le capital financier mondial est de plus en plus enchevêtré dans les conflits fonciers, au fur et à mesure que l'exploitation du pétrole, des minerais et des ressources naturelles s'est étendue dans de nouvelles enclaves africaines qui mettent en exergue la dimension externe du développement dévoyé. Ces processus définissent la signification de la terre dans l'économie politique du développement africain. Cette étude examine les contradictions sociales et politiques complexes qui façonnent les luttes pour la terre, y compris leur trajectoire coloniale et post-indépendance. Il y est discuté de l'échec des réformes foncières néo-libérales, reposant sur les lois du marché, et leur confrontation aux demandes populaires de réformes en vue d'une redistribution.

\section{Introduction}

Africa's land questions are a critical factor in defining contemporary social transformation and in shaping the continent's development trajectory. Land scarcity and access constraints are the main source of persistent food insecurity, rural poverty, distorted accumulation and development, as well as of the escalating conflicts over land rights. Citizenship, as proscribed by contested land rights that mark 'belonging', is increasingly being reconfigured (Geschiere and Nyamnjoh 2000). Increased struggles for land reflect the absence of a development capable of absorbing the employment and consumption needs of growing populations into industrialising and diversified economies. The agrarian transition has so far failed to materialise, while the home market remains disarticulated. The unresolved land question in Africa also highlights the failure to address historical social justice and contemporary inequality issues, especially through neo-liberal reforms (Moyo 2000; Palmer 2002). Land property relations are increasingly distorted by growing land concentration and exclusion, the expansion of private landed property and the deepening of extroverted (export) capitalist relations of agrarian production, alongside increased food insecurity and food imports (aid dependence), the continued decline of the value of growing agrarian exports and the collapse of Africa's nascent agro-industrial base.

Recent studies on land in Africa (Quan 2000; Palmer 2002; World Bank 2002; EU 2004) have tended to focus on customary land tenure and 'livelihood' issues rather than on the larger land questions underlying agrarian, mining and industrial development. Although some scholars have questioned whether Africa has a significant land question except in former settler colonies, given the absence of widespread colonial land expropriation, the unresolved agrarian question throughout the continent is widely recognised (Mafeje 1999). This suggests the need to understand the place of land in 
longer-term processes of capital accumulation and proletarianisation (Arrighi 1978) as well as the effects of land administration systems on development and democratisation (Mamdani 1996).

\section{Land reform, the agrarian question and national development}

Land reform is a necessary but not sufficient condition for national development. The link between land reform and national development was widely acknowledged in an earlier period of development (1950s-1970s), although implementation was generally limited and contingent on 'Cold War' geopolitics (Yeros 2002b). From the 1980s onwards, under the influence of international finance and neo-liberal economics, state-led interventionist land reform was removed from the development agenda and replaced by a concerted market-based land policy. This policy framework pursued the privatisation and commercialisation of land and focused on land transfers according to market principles (Moyo and Yeros 2005a).

The neo-liberal policy framework has had two implications for national development. It abandoned the project of integration of agriculture and industry on a national basis, promoting instead their integration into global markets, and it also aggravated economic and social insecurities, intensified migration to urban areas and created a deepening pattern of maldevelopment (Moyo and Yeros 2005a). With the end of the Cold War, the end of white rule in southern Africa, the deepening of the development crisis in Africa and the emergence of various land crises (e.g., in Zimbabwe and Côte d'Ivoire) and the re-emergence of rural-based land reform movements since the $1990 \mathrm{~s}$, land reform has returned to the political and poverty agenda, but less to the development agenda. The practice of land reform continues to be based on market principles, while the theory of land reform has not yet articulated a coherent purpose for land reform in relation to national development. These trends reflect ideological and political differences that are manifested in various forms of organised and sporadic conflicts over land.

Land reform is a fundamental dimension of the agrarian question, and the agrarian question is a fundamental dimension of the national question. The classic agrarian question, concerned with the transition from feudal/agrarian society to capitalist/industrial society, has been only partly resolved by the course of development in the postwar period. While capitalist relations of production have displaced feudal-type relations virtually everywhere, few if any parts of the continent have experienced industrialisation. Indeed the international division of labour in industrial and agricultural production has persisted with only minor changes since the 1960s. The integration of Northern economies amongst themselves and with a small number of new industrial 
satellites has deepened, and a new division of labour within global industry and agriculture, based on technological capabilities, financial privileges and mercantilist trade policies, has emerged (Moyo and Yeros 2005a). These trends have increased popular dependence on land for social reproduction, while agrarian productivity potentials remain unrealised.

With the failure to resolve the agrarian question, the national question remains unresolved, as national self-determination, born of the struggles against imperialism in the twentieth century, has failed to deliver development. Indeed there has been a retreat from the terms of the national question itself; under the auspices of international capital, and by means of the liberalisation of economies and an ideology of 'globalisation', the end of national sovereignty and the system of nation states has been widely proclaimed (Moyo and Yeros 2005a). However, as the post-war period of global accumulation reaches its limits, characterised by overproduction in world industry and agriculture as well as by the financialisation of capital, the national question re-emerges with particular urgency.

During the last quarter century many economic and political facts have changed both within African countries and between them. National capital has increasingly been absorbed by international capital except in rare cases (e.g., South Africa), agricultural mechanisation has grown and national economies have become much more dependent on international markets. Externally the international monetary system is less committed to stable exchange rates and fair adjustment mechanisms between commercial surplus and deficit states. The key international currency remains under the jurisdiction of a single state (USA). Capital controls have been removed (under structural adjustments), and international financial markets now fully control national macroeconomic policies. The new system of trade rules and procedures (under the World Trade Organization) has deepened liberalisation and subordinated more African states to mercantilist trading partners from the West, although the emerging trend of Chinese capital in search of African oil and minerals slightly tilts this picture. While regionalism has been renewed through the African Union, and is a potentially progressive process, in practice, regional integration has been undermined by following the priorities of global integration rather than those of the African home market. These conditions suggest the need for an alternative national development strategy based on a credible agrarian reform agenda.

Agrarian reform, including land reform, was always intended to serve national industrialisation. However, recent African land debates have underplayed the national development potential of agrarian reform by counterpoising three general views on the purpose of agrarian reform: the 'social', the 'economic' and the 'political' (Moyo and Yeros 2005a). The social 
version of land reform is currently predominant in many of Africa's poverty reduction debates (Palmer 2000; Quan 2000; World Bank 2002). This implicitly argues that the existing African agro-industrial base (that which survived structural adjustment and liberalisation) is sufficient and competitive enough and that agricultural export capacity is rewarding but limited by weak foreign investment incentives and to a lesser degree by Northern market distortions. As such any intervention in the agrarian sector should be confined to providing some land tenure security, especially to dispossessed and unemployed workers, until more 'livelihoods' or non-farm employment can be generated elsewhere in the informal economy (Palmer 2000). From this point of view it is also argued that the problem of employment can no longer be dealt with by means of agrarian reform (Bryceson 2000), as had been the formula in the 1950s and 1960s, for this would destroy existing agro-industry. Some argue that smaller-scale production is inherently unproductive and needs to be complemented by growing capital-intensive, large-scale farming (Sender and Johnston 2004) and that the growing urbanisation trends of the last two decades are irreversible, while reflecting de-agrarianisation (Bryceson 2000) and a new urban modernity requiring 'de Soto-type' land tenure formalisation to assign value to ghettoic assets (de Soto 2000). Thus, land reform debates that focus on poverty reduction tend to be informed by a social welfarist perspective on development, reflected in various land tenure programmes in Benin, Malawi, Tanzania and so forth.

The economic version of the perspective on land reform promotes the idea that smaller-scale agriculture could reach a reasonable level of productivity and that land reform is a useful basis for development, since urbanisation is partly reversible (Lipton 1976). This view emphasises the 'family farm' and essentially calls for the promotion of middle capitalist farms utilising wage labour. These would have the potential to absorb labour, depending on the appropriateness of the technologies developed, since these could undermine employment in the longer term (Moyo and Yeros 2005a). Yet for the middle-sized farm to realise its potential of redirecting production to the national market and hence to synergise dynamically with domestic wages, a reversal of neo-liberal policies would be required. States would instead have to adopt a concerted national development policy framework seeking the integration of the home market (Moyo and Yeros 2005a). This framework of petty agrarian commodity production promotion has been advanced in numerous African countries (Bernstein 2005) with the social differentiation process generating less than 10 percent of the middle farm among the peasantry (Eicher and Rukuni 1995).

A related current in this debate sees economic potential in a bifurcated agricultural sector in which large-scale farming specialises in the export of 
high-value crops while smaller-scale farming specialises in domestic provision. However, the current contradictions between small-scale and largescale farming in the economic and political process are not expected to attenuate but accentuate, and the bifurcated model would demand a generalised shift in the national policy framework that would challenge the historical privileges (in terms of credit, services, electricity, irrigation and marketing infrastructure) enjoyed by the large-scale farming sector. This bimodal agrarian policy framework has been vigorously pursued recently in Botswana, the Congo, Mozambique, Nigeria and Uganda, especially with the aid of relocating white Zimbabwean farmers. Opponents argue that the benefits of largescale farming are overestimated, given its historical privileges, social costs and environmental sustainability (Moyo 2005). This argument sees value in a national strategy of partial 'delinking' from the global market but faces the chronic foreign-exchange dilemma as well as national and international opposition (Moyo 2005).

The political version of land reform also has two main tendencies that are not necessarily distinct from economic thinking: the 'micro' and 'macro' tendencies. The micro tendency sees political value in land reform as a means to dissolve non-capitalist relations of production or excessively concentrated power structures where they continue to exist at local and regional levels. Land reform in this view should be confined to a targeted local and regional democratisation project and not to a national project of structural transformation. By contrast the macro tendency views land reform as a means of dissolving the political power of large agrarian capital operating in tandem with international capital and has an interest in the maintenance of an extroverted model of accumulation (Moyo 2001). This tendency sees large-scale land reform as a political precondition for the implementation of a national development policy for the integration of the home market. It considers private landed property an obstacle to the mobilisation of such a national project.

\section{African land reforms, primitive accumulation and development}

The economic and material foundation of the African state rests largely on primary resources extraction and export activities in agriculture, oil, mining and other natural resources (forestry, wildlife, biodiversity exploitation). With a few exceptions of countries that have experienced capital-intensive industrial growth, such as South Africa, the control of land and natural resources and their product markets is a dominant factor in the mainstream processes of capital accumulation and social reproduction. These determine the revenues and resource base of most African states, such that power structures 
and politics are heavily influenced by control of land even where mineral rents are critical.

Large tracts of lands in many African countries are controlled by the state through various property relations. State agencies hold land directly and indirectly, the state has powers over local authorities that control land under customary tenure and, through its regulatory instruments, the state wields powers over statutory lands, particularly leasehold lands and land markets. State power and political hegemony over national territory is expressed specifically through powers over the allocation of land and related resources, the regulation of land tenures and land use and through state structures responsible for the resolution of disputes that arise from competing claims over land. Such control is accompanied by extensive state influence over the allocation and use of water and natural resources, and, through this and other economic policies, the state directs financial resources and incentives that influence patterns of land utilisation. Thus African states broker and build power structures and accumulation largely through the control of land and natural resource allocations using various systems of distribution. Land reforms represent changes in the extant land resource allocations, regulatory powers and institutions of the state, traditional authorities and emerging forms of capital.

The African state, situated within the context of neocolonial class formation processes and extroverted economic structures, is itself shaped by differentiated internal social forces that define political power and accumulation, but these remain subordinated to external capital and markets. Yet the state is central to 'primitive accumulation' in general and access to major national socioeconomic resources in particular, given the absence of a mature indigenous bourgeoisie. Access to political office can be critical to the direction of accumulation. Weak neocolonial African states, whether these were formerly settler colonies or not, retain different degrees of 'customary' regimes of authority, including some forms akin to remnants of semi-feudal regimes, such as those found in Morocco, Ethiopia and northern Nigeria. These play a critical role, together with the central and local governments, in the control and allocation of land.

The primary contradiction facing neo-liberal development strategies and democratic struggles remains the unequally globalised markets. Trade relations are intended to replace state interventions as an instrument of development for the internal needs of society within an integrated economy, based on improving resource and technical productivity and returns to labour at levels adequate for basic social reproduction. State interventions for development, tied under increasingly market-based relations of resource (including land) control, have tended to exclude the weakly organised and favoured 
domestic elites and foreign capital through the manipulation of the markets and administrative processes that govern resources such as land and water.

The control of land has increasingly become a key source of mobilising power through electoral politics in which capital and class power direct struggles for democratisation and development. Land reforms can be critical sites of political struggles, when class and race power structures are unevenly pitched in relation to the interests of external capital and in the context of unequal land distributions, as the Zimbabwe experience shows. The 1992 Kenya elections outcome, for example, was grounded in cynical strategies of politicians who manipulated long-standing but latent inter-ethnic disputes over land into violent confrontations (Moyo 2005). Thus, the nature and form of state control and the ideological grounding of the ruling incumbents can be critical to the form and content of land reforms.

The nature of Africa's current intellectual and policy debates on land reflects important ideological and political contestations around the definition of land and agrarian questions, hence the trajectory of land and agrarian reform that is required to undergird sustainable development and the role of the state vis-à-vis domestic markets (including agrarian markets) as well as international markets. The neo-liberal agenda emphasises market liberalisation within a global hegemonic project that subordinates the African nationstate accumulation project to global finance capital. The contradictions of this neo-liberal trajectory manifest themselves partly in Africa's land and agrarian questions, ineffective land reforms and the mobilisation of various social forces around land.

\section{Unique features of the African land question}

There are some uniquely African social features that define its land questions and approaches to land reform, including why the dominant emphasis on land tenure reform has evolved. Mafeje (2003) emphasises the absence, at the advent of African colonialisation, of widespread purely feudal political formations based on the specific social relations of production in which land and labour processes are founded on serfdom or its variants, essentially the extraction of surplus value from serfs by landlords through ground rents using primitive forms of land rental allotments, and through the mandatory provision of different forms of 'bonded' or 'unfree' labour services such as sharecropping. The other tributary exactions on the peasantry under feudalism were uncommon in Africa and not as intense where they obtained. Mafeje (2003) points out that most rural African societies were structured around lineage-based communal structures of political authority and social organisation in which access to land was founded on recognised and universal usufruct rights allocated to families (both pastoral and sedentary) of given 
lineage groupings (Moyo 2004). Such land rights also included those eventually allocated to assimilated 'slaves', migrants and settlers, as Mamdani (2001) and others note.

This means that African households held land and mobilised their labour relations relatively autonomously of the ruling lineages and chiefs, mainly for their own consumption needs and secondarily for social or communal projects on a minor scale. Under these conditions production for trade occurred on a small but increasing scale since colonialism (Moyo 2004). Amin (1972) has argued that these African social formations had some exploitative elements of tributary social relations of production. These can be adduced from the contributions that households made, from small parts of the household product and labour, to the rulers' social projects (e.g., the king's fields, granary reserves and so forth). The essential issue that distinguishes the African land question from elsewhere is the absence of rural social relations of production based on serfdom, such as land renting and bonded labour, in a context where monopoly over land by a few landlords did not exist. Colonialism extended the extroversion of production and the process of surplus value extraction through the control of markets and extra-economic forces, but left the land and labour relations generically free.

Under colonialism 'indirect rule' modified the organisation of peasant societies through contrived changes to the procedures of customary rule and of leadership and directed peasant production towards generalised petty commodity production, mainly through the control of finance, markets and infrastructures (Moyo 2004). While migrant labour processes were engineered almost everywhere, within limited geographic confines in settler Africa they accompanied extensive and institutionalised land expropriations that led to the proletarianisation of large segments of peasant labour, generating largescale landlessness and land shortages alongside semi-proletarianisation. Under indirect rule the customary systems of authority with regard to land tenure were thus retained but adapted to suit the needs of the state to excise some lands and allocate them to specific production schemes or classes, and these allowed lineage leaders larger land endowments (Moyo 2005).

While the dichotomy which defines non-settler and settler African land questions, based on large-scale historical land alienation remains, it has increasingly become less acute in some regions of given countries because of generalised but location specific narrow forms of land concentration. This concentration has emerged both from 'below' and 'above' - from below through internal social differentiation and from above through excision of lands to elites using state land administration structures and emerging land markets. This emphasises the fact that the African neocolonial state has been 'activist' in promoting agrarian capitalist change in a manner that has sup- 
ported land concentration among capitalist farmers and enabled the dominant classes to marginalise peasants and workers. On a continental scale these processes nonetheless suggest that neither large-scale land alienation processes nor landlessness nor total proletarianisation nor bonded forms of rural labour have resulted. They point to a diffuse but significant structure of land concentration and marginalisation processes that are socially and politically significant (Moyo 2004).

\section{Resilient African peasantries, semi-proletarianisation and agrarian reform}

The prevalence of semi-proletarianisation - worker peasants - alongside the retention of large peasantry, or of small cultivators (Mafeje 1997), means that in general African rural societies retain households with independent landholdings, albeit at a diminishing scale and on increasingly marginalised lands. Critically their agricultural production and land use activities and relations of production are restricted by the quality and scale of land available and by state agrarian policies as well as markets which extract significant surplus value from them. African land and agrarian reforms therefore need to redress these land inequities and direct land use towards internally beneficial and articulated development for the transformation of Africa's peasantry (Moyo 2004).

The peasantry - small-scale/family agriculturalists operating within the generalised system of commodity production - does not constitute a class in itself, but inherent in it are the antagonistic tendencies of proletarian and proprietor (Moyo and Yeros 2005a). The ideal peasant household reproduces itself as both capital and labour simultaneously and in internal contradiction, but this combination of capital and labour is not spread evenly within the peasantry for two main reasons (Moyo and Yeros 2005a). First, the peasantry is differentiated between rich, middle and poor petty commodity producers, a spectrum that ranges from the capitalist that employs labour-power beyond the family to the semi-proletarian that sells it. As such, the middle peasantry is the only category that embodies the ideal type of petty-bourgeois production, neither managing to hire nor sell labour-power - and which in turn is rare. Second, the combination of capital and labour is not spread evenly within single households either differentiated by gender or generation; patriarchs control the means of production, while women and children provide unwaged labour. This may appear on the surface as a 'different' mode of production, but it has been argued convincingly that petty-commodity production is firmly embedded in the capitalist system and in fact is a normal feature of capitalist society, even if a subordinate and unstable one (Gibbon and Neocosmos 1985). 
Under capitalism the peasantry remains in a state of flux within the centre-periphery structure spawned by colonialism, as proletarianisation co-exists with peasantisation and semi-proletarianisation. The form and scale of the actually existing peasantry in Africa is both an empirical and an interpretive problem to be understood from the composition of household income by source, including non-exchangeable sources of sustenance and from an analysis of household residential patterns as between town and country (Gibbon and Neocosmos 1985). It has been argued that under structural adjustment peasants have become 'problematic', as they are 'multi-occupational, straddling urban and rural residences, and flooding labour markets' (Bryceson 2000a). Yet the African peasantry has evolved in this way for much of the twentieth century.

However structural adjustment has been accompanied by intensified migration. Africa now has the fastest rate of urbanisation in the world (3.5 percent annually) and nearly 40 percent of the population is now urbanised. Migration should not be taken to mean full proletarianisation or permanent urbanisation, but the spreading of risk in highly adverse circumstances. Had this urbanisation been accompanied by industrialisation and job formation, the conclusion could have well been otherwise. The reality is different urbanisation alongside de-industrialisation and retrenchments. Urbanisation takes the predominant form of illegal and unplanned settlement. It is notable in this connection that migration is not merely one-way, as workers retrenched from mines and farms are also known to seek peasantisation, or as urbanites enter the land reform process. This situation is mirrored by trends in Latin America that are not substantially different even if the population there is nearly twice as urbanised and still urbanising (Moyo and Yeros 2005a).

Intensified migration has been a two-way process in Latin America as well, as opposed to secular urbanisation, which Kay terms the 'ruralisation of urban areas' and 'urbanisation of rural areas' (cited in Bryceson et al. 2000), whereby rural and urban workers compete both for jobs, including agricultural jobs, and for residential plots in both urban and rural areas. It has also been observed that retrenched workers from mines and industry have joined this struggle and have also sought to become peasants themselves, the most prominent case being in Bolivia, where former miners have taken up coca production (Petras 1997). The semi-proletarianisation thesis is disputed by those who see urbanisation and proletarianisation as definitive and therefore dismiss agrarian reform as anachronistic, especially Kay's particular version of semi-proletarianisation, which underestimates the political significance of the countryside and even combines with the 'end of land reform' thesis to write off an alternative pattern of accumulation (Bryceson et al. 2000). The semi-proletarianisation thesis has yet to be overturned ei- 
ther in theory or in practice, especially given that agrarian change within the contemporary centre-periphery structure does not provide for massive population relocations to the north.

The rise of a richer class of peasants alongside a majority who became semi-proletarianised or landless means that full proletarianisation has been generally forestalled, not least by state action as well as by rural households that hold onto a plot of land and maintain the dual income strategy of pettycommodity production and wage labour. Rural non-farm activities and markets have proliferated, such that between 30 and 40 percent of household incomes are now derived from off-farm sources. The transition to capitalism in the periphery has thus taken place under disarticulated accumulation and in subordination to the accumulation needs of the centre. In consequence the transition has not been characterised by an 'American path', as identified by Lenin - that is, a broad-based accumulation by petty-commodity producers 'from below' - but by varied paths.

Where the neo-liberal social agenda failed spectacularly in Zimbabwe, large-scale re-peasantisation has taken place outside the control of the World Bank, hence the penalties imposed from the North, but a new pattern of accumulation from below has not yet emerged (Moyo and Yeros 2005a). Such trends are now 'normal' processes of agrarian change in the African periphery under neo-liberalism, where rural populations have been subjected to unfettered market forces, where they have struggled for re-peasantisation among other political and economic ends and have in effect struggled to reproduce functional dualism largely on their own, with variable success and different and contingent levels of support from state and non-state agencies. Alongside this semi-proletarianisation process, various social hierarchies derived from gender, generation, race, caste and ethnicity have intensified under capitalism and functional dualism (Yeros 2002a). ${ }^{1}$ In a contemporary world disarticulated accumulation and its corollary, semi-proletarianisation, provide the structural economic basis for the flourishing of powerful social hierarchies that either fuse with class (e.g., race, caste) or cut across it (gender) and reproduce apparently non-capitalist forms of 'landlordism', even despite the historical culmination of the 'junker path' (Yeros 2002a). The synergy between class and race is notable in Zimbabwe, South Africa and Namibia, where historical domination and the process of resistance have fused class and race discourses (Moyo and Yeros 2005a).

\section{Land and agrarian questions in settler Africa}

Another critical factor which defines the African land question in relation to its development path is the legacy of the settler colonial land and livestock expropriations that accompanied colonial conquest and the nature and ex- 
tent of reparations that are demanded, based on 'living memory' and as an integral element of resolving the 'national' question (Moyo 2004). This nationalist land question of sovereign right and of redressing racial and ethnic imbalances in property and economic relations has tended to be underestimated in spite of the numerous indigenous land struggles evident today. Land reform programmes in this situation, where compensation of current large landholders is considered almost normative, face popular expectations that former colonial masters should pay the victims of current land reform expropriations, if not also the victims of colonial expropriation, who have suffered long-term loss (Mamdani 2001). Demands for colonial land reparations have been made in Kenya, Zimbabwe and Namibia and on a smaller scale in Botswana and Swaziland, as has been the case in other nations with a history of settler colonial land expropriations. In some countries where historic land reforms occurred, for example, in Japan and Taiwan, these were financially supported by former colonial or imperial powers, especially in the context of cold war political hegemonic efforts.

Reparations for colonial land losses in Africa have not been adequately addressed (Moyo 2004). African governments, the Zimbabwe government in particular, allege that racism and protection by international donors of their land-owning 'kith and kin' and of their capital in Africa is at the centre of the land reform dilemma and of the current political controversy. Current structural adjustment programmes (SAPs) and poverty reduction strategies, which provide lending and development assistance on condition of neo-liberal economic and governance reforms, undermine national capacities to redress these land grievances according to the rule of law. This feature emphasises the colonial and external dimension of Africa's land question and reform processes, as well as the political controversy of market-driven land reform strategies in the context of neo-liberal 'globalisation' (Moyo 2004).

Consequently demands for agrarian reform in settler Africa have struck at the heart of the dominant national/cultural identities through which the conditions of super-exploitation are reproduced. In Africa, however, the issues of race and class have been strongly politicised for a longer period (Fanon 1961; Cabral 1979), and armed national liberation struggles against colonialism intensified these. The attainment of majority rule across the continent, within the neocolonial framework, was characterised by the nurturing of small, indigenous, extroverted bourgeoisies with an interest in defending the disarticulated pattern of accumulation, while in southern Africa neocolonialism coincided with structural adjustment. National politics have been galvanised by rural and urban class struggles through growing class differentiation among blacks. This has given impetus to a new period of inter-capitalist conflict between emergent black bourgeoisies and established 
capital, both extroverted and both bidding over the land question. The result has been a stark bifurcation of the national question. On the one hand indigenous capital has confronted settler and foreign capital, transforming the meaning of 'national liberation' in its own terms and hijacking land reform, while on the other hand the historical realities of class and race persist, characterised by functional dualism within a white supremacist framework, including the racialised landlordisms to which it gives rise (Moyo 2001; Rutherford 2001; Yeros 2002b).

\section{Three dimensions of Africa's land and agrarian question ${ }^{2}$}

Three land questions therefore dominate the political economy of development in Africa today. These are the increasing concentration of land control and restricted access to marginalised rural and urban populations, the expansion of marketised land transactions and the persistence of land-use processes that distort agrarian transition. Land scarcity and denial of access to natural resources by large landholders and the state through laws that exclude the majority and that privatise public resources, all contribute to human distress, poverty, landlessness and homelessness. In some situations, it is the scarcity of arable land that is at stake (e.g., in North Africa), while in others (e.g., in West Africa) it is the system of land administration and conflicts between the state and local communities and various other social groups (men, migrants, women, urbanites, civil servants, youths and poor households) that are problematic (Amanor 2003). In former settler colonies, it is the challenge of land redistribution and related land struggles that are dominant.

\section{The land distribution question: Equity and socio-political relations}

Land distribution inequalities in Africa vary in their broad character depending on the degree of colonial history, foreign ownership and internal class and ethno-regional differential. Settler land expropriation varied in Africa. It was most extensive in Kenya, South Africa, Zimbabwe and Namibia but also occurred to a lesser extent in Mozambique, Swaziland, Botswana, Tanzania and Zambia. The largest scale of white settler land expropriation occurred in South Africa, where 87 percent of the land was alienated. After independence white settler populations in all these countries tended to decrease, although the proportion of land held by white minorities has not decreased proportionately. Instead there has been a gradual increase in foreign landholdings in countries such as Mozambique, Zambia and Malawi in the context of renewed interest by international capital in natural resources based around tourism and mining (Moyo 2005). In Malawi during the last three years long-term Asian residents have increasingly been identified as 'for- 
eign' landowners, largely on racial and dual citizenship grounds, given that land policy reforms prohibit foreign land ownership. Absentee land ownership exacerbates feelings against foreign land ownership. In Namibia corporate ownership of lands hides the influx of foreign landowners, particularly those who are shifting land use from agriculture to tourism. Racially based differentiation of economic power and wealth associated with some degree of land control remains a source of land conflicts. Even in some non-settler African countries, small foreign immigrant populations such as the Asians in East Africa tend to be associated with large freehold and leasehold landholdings.

Land distribution problems in non-settler countries occurred initially through rural differentiation processes, which heightened from the 1970s and escalated in the 1990s. The maturation of an African petit bourgeoisie after independence saw new landholding concentrations among retired public servants, professionals, indigenous business people and other urban elites. These social forces emerged from earlier nationalist, political and administrative leaderships, traditional elites and new post-independence middle-class elements whose accumulation treadmill focused on agrarian exports. Such rural differentiation, alongside the growth of poor rural peasantry and semiproletarian populations that straddle the rural and urban divide, explains the demand for land reform policies in favour of elites. Evidence from Botswana, Kenya, Malawi, Mozambique and Zambia also reveals that rural land inequality has grown in line with structural adjustment programmes. Differential access to land and the growth of land concentration have emerged both from 'below' and from 'above'.

Colonial land injustices and current land policies have led to increased differentiation in the control of and access to land. Increasingly land ownership patterns are derived from endowments arising from class differentiation strategies that emerged in the colonial era (Lumumba and Kanyinga 2003) and have led to growing landlessness. For example, Kenya's land law grants enormous powers of control of land to the president, who holds land in trust for the state. Kenyan presidents, however, have tended to grant land to a few individuals and corporate interests. This process has affected the majority of the lands utilised by pastoralists, who occupy and use over 60 percent of the Kenya landmass. Thus, from above, land allocation and land reform policies have promoted land accumulation by the direct official provision and private grabbing of large landholdings by the elite. From below processes of local agrarian and power differentiation have encouraged local elites to amass larger landholdings amidst growing land scarcity and landlessness. This has entailed widespread situations in which local agrarian capitalists have emerged and acquired larger-than-average tracts of land through internal social differ- 
entiation processes. These processes include resource accumulation from land grabbing, from various state resources and from the accumulation of petty agricultural savings, wages and remittances and other non-farm sources. Local land concentration also entails situations in which traditional leaders, elders and indigenous 'settlers' have hoarded larger land parcels of better quality. Land tenure reforms tend to formally recognise discriminatory customary tenure rules or to condone their persistent abuse by local elites and local state functionaries, as well to introduce statutory tenures for the benefit of these elites. While unequal landholding structures are not as extreme as in the white settler territories, processes of land concentration now occur on a significant scale.

Colonial and post-independence land policies also tended to partition national economies into ethno-regional enclaves of unequal growth, where land and resource concentration occurred alongside marginalisation. Land conflicts take the shape of 'ethnic' struggles among pastoralist groups competing for the control of grazing lands and water supplies, especially during droughts (Flintan and Tamrat 2002). Such land conflicts escalated following the demarcation of boundaries that fragmented pastoral groups and impeded cross-border movements and undermined the viability of customary land and resource-use systems. Minority groups have suffered substantially, and land distribution conflicts affecting some ethnic groups, especially minority 'indigenous' groups (such as the San/Bushmen in Botswana and the Herero in Namibia) are common in some countries, especially where post-independence land expropriations by the state have facilitated or led to the reallocation of land to local elites and foreign capital. In some countries the spatial re-ordering of villages and families was instrumentalised by the colonialists to consolidate ethnic-based power structures of their choice and to create a framework within which taxes could be collected, migration regulated and selected land allocation strategies pursued to suit their interests. Thus many African social or ethnic conflicts are structured by the unequal control of land and natural resources, depending on the histories of land control, farming systems and political structures. Unequal land distribution also arises from the growing tendency for land concessions and sale to foreign companies through investment agreements in agriculture, tourism, forestry and urban land investments. Multinational companies have become a critical force in the unequal control of land, emphasising the importance of the international dimension of the land question.

\section{Land rights, private property and markets}

A major dimension of Africa's land and agrarian question has been the search by both colonial and post-independence states, as well as emergent landholding classes, including foreign capital, for the transformation of custom- 
ary land tenures and property rights into private landed property and the establishment of land markets based on individual freehold and leasehold titles to rural and urban land. The experience with land tenure reforms is perhaps best documented in West and East Africa. Several countries in West Africa have pursued land registration as a step towards creating land markets (Moyo 2003). Land tenure policy and legislative reforms have escalated in West Africa since the early 1990s, with countries such as Burkina Faso, Guinea, Guinea-Bissau and Mauritania introducing the concept of private property in response to such pressures (Delville et al. 2002). When empirical evidence questioned the relevance of privatisation in promoting security of tenure and the lack of marked differences in investment between customary tenure systems and private property rights, the land tenure policy debate shifted towards 'local rights recognition' (Delville et al. 2002). The increased commercialisation and expropriation of land as a result of the production of export crops set in motion serious conflicts, increased land pressure and resulted in the growth of a land market in Ghana (Amanor 2003). These tenure reforms essentially veer towards establishing land markets over the longterm.

In East Africa and the Horn, post-independence land tenure reforms have ranged from individualisation and privatisation, as in Burundi, Kenya and the Comoros to a collectivist approach in Tanzania and Ethiopia (Moyo 2003). Most countries in East Africa have provided some legal recognition to indigenous customary land tenure (Bruce 1996). Tanzania, Ethiopia and Eritrea abolished private ownership and sought to replace indigenous tenure systems with alternative community-based tenure reforms. In North Africa tenure reforms took ascendance from the 1970s with an incomplete process of registration and certification of ownership in Tunisia and Morocco. The process of privatisation of state and collectively owned lands has also been slow, as has the emergence of land markets.

The widespread trend in Africa in the 1970s and 1980s towards individualisation and titling of customary lands was sponsored by donors who were convinced of the superiority of private property rights (Platteau 1996). When these schemes failed to gain social and political acceptance, the World Bank in the 1990s argued that, as population pressure increased, societies would spontaneously evolve new property relations and land markets and that the task of African governments should be to formalise such evolving property relations through titling (Moyo 2003). However, contrary to the claim of recognising local land rights, the establishment of land titles and registers has also facilitated a new wave of land alienation and investment by domestic and foreign entrepreneurs. 
In general land conflicts arising from attempts to market land by assigning exclusive land rights to individuals have led to a conflictual relationship over the power of the state to allocate land vis-à-vis that of customary law authorities. Control over land allocation and concession procedures in postindependent African states tends to be increasingly delegated to elected or appointed rural councils, leading to conflicts between formal law and customary land rights, for example, in Côte d'Ivoire and Burkina Faso (Delville 1999) and in Ethiopia (Submarian 1996). Although the state has taken over the absolute right of land allocation, these local authorities usually remain legitimate in the eyes of the community and continue to enjoy considerable political power over land management systems (Submarian 1996).

In many African countries a dual legal system for land conflict management and adjudication has been the source of many conflicts and contradiction over land rights (Tsikata 1991; Shivji 1998; Lastarria-Cornhiel 2002). Customary law in land matters in southern Africa, for example, applies mainly to indigenous Africans, while the formal legal system is reserved for white settler land markets (Mamdani 1996). African countries with ethnic groups that practice different customary legal systems may or may not recognise the dominant systems of customary adjudication. In those countries with significant Muslim populations (such as Nigeria, Tanzania and Sudan) the adoption of Islamic family laws in predominantly Muslim regions contradicts both the customary laws and received legislation on land that applies to other regions with different legal traditions (Lastarria-Cornhiel 2002).

Many communities resent the heavier presence of administrators (besides the traditional leaders) in customary systems of tenure that is found in freehold tenure regimes, perceiving it as restricting (and in some cases criminalising) use of natural resources and imposing land use policies that the local people may not like. The fact that individuals under freehold tenure, including those on plantation estates, tend to have more rights to the management of their land creates the problem of the assumed superiority or inferiority of the different forms of tenure, when in fact these problems are based on the form of land administration.

Thus tenure inequities are reinforced by the fact that the expropriation of land for 'commercial' and 'social' development is usually carried out by central state institutions that, in the name of development and national interest allocate land to state projects and private commercial interests to the exclusion of the poor (Amanor 2003). When rural people oppose this expropriation, the legal channels available to readdress their concerns are limited, since the state has created the legal framework that has already initiated the process of expropriation. This is usually carried out by unrepresentative land bodies, including chiefs, elders, and others in leadership positions at ward 
level (Shivji 1998; Amanor 2002; Murombedzi 1999). While chiefs are often the partners of the state in expropriating farm land, they are recognised by the state as the legitimate representatives of the people, so that their role in the mediation of land conflicts is usually overshadowed by transmitting government orders to the rural people and ensuring compliance with government policies (Amanor 2003).

\section{Extroverted agrarian development and distorted home markets}

A long-standing land question in Africa is the manner in which development policies, including economic incentives and public allocations, have directed the use of land in ways that are not beneficial for national development and that favour distorted accumulation by a small elite and foreign capital. The productive purposes of land use, including the types of commodities produced and their trade and domestic benefits, and the levels of productivity promoted by these policies, have tended to remain extroverted.

Land use policies currently undervalue land, largely by allocating land and related resources to commodities with poor returns and domestic linkages. This external co-optation by neo-liberal policies has led to the demise of African agriculture, expanded food insecurity, dependence on food imports and food aid and the inability of agriculture to accumulate investible resources and finance itself without resorting to external debt. The trend towards expanding land use patterns for exports has led not only to the loss of local livelihoods (pastoralism and peasant cropping systems) but also to increased conflicts over the control of land and gradual processes of land alienation. One controversial trend emanating from the liberalisation of land use policies is the conversion of farming land to exclusively wildlife and tourism-based land uses through the consolidation of large-scale farms into even larger scale 'conservancies'. These land uses are justified as being the most environmentally, socially and economically sustainable management of land and natural resources in fragile areas. But these conservancies add to the previous exclusion of peasantries from substantial lands by the state in the name of attracting national, regional and international capital in the tourism, forestry and biotechnology sectors. They remove the visibility of the human face of individual land ownership from the struggles over land and shift these to abstract legal entities of ubiquitous domicile, justified through putatively benign environmental theologies (Moyo 2000). Thus, the socioeconomic face of rural differentiation through large-scale land ownership and use for external markets is transformed into remote public and private shareholding structures that extol modern common property management regimes and decry traditional communal tenures.

Tourism, environmentalism and related markets have thus created a new land frontier in African states in which various 'stakeholders' at the local, 
district, provincial, national and international levels, involving private, state, NGO and community actors, are engaged in struggles for the exploration and preservation of new forms of biodiversity and the methods of their economic and social exploitation (Moyo 2000). This preferential allocation of state resources to land uses aimed at the reproduction of nature in state lands and in parks and forests emphasises their short-term commercial and macroeconomic value to the state, elites and foreign capital, rather than any interest in rural poverty reduction. Land use policies and regulations tend to be based on the view that large farms are critical for agricultural export growth and that small producers should focus on production for their own consumption and domestic markets. In most of Africa, except perhaps in western and northeastern areas, relatively larger landholdings under freehold or leasehold tenure are supported by the state because of their perceived superiority for the production of agricultural produce for export. Yet smallholders on customary land grow almost all the coffee exports in Ethiopia, Kenya, Rwanda, Tanzania and Uganda. The same is true for tea, beans and various horticulture products in Kenya. In addition there are many smallholder cocoa farmers in West Africa and smallholder cotton farmers in western, eastern and southern Africa. At the same time evidence suggests that smallholder production of food for own consumption has become critical for the food security and sustainable livelihoods of the majority of Africa's people.

Much scholarship on Africa tends to consider national internal agrarian policy deficiencies to be the main cause of Africa's agricultural and rural problems. Yet the most striking feature of African agricultural performance over the last three decades is the growing rural income distribution inequalities and broader social differentiation (Ghai and Radwan 1983) consequent upon the expansion of rural markets and of negative global economic integration. In historical perspective these interpretations of the causes of the agrarian crisis reflect poorly on the African nationalist agenda, because it has delivered neither industrial development nor stability and has generated greater social conflict over land and other natural resources.

Shifts in African land use patterns have always been a highly contested dimension of its agrarian question. Land use policies increasingly uphold a moral and socioeconomic value in which allocating prime land to extroverted (export) cropping, livestock and wildlife and tourism uses is considered of greater utility than land use for national economic integration to satisfy the home market as defined by the land needs of the majority of the rural and urban poor. Instead a few large landholders, and the animals themselves, are privileged by the exclusion of peasantries from vast tracts of land and natural resources and state financial allocations. Policies and regulations that directly or indirectly orient land use towards minority capitalist classes and 
external markets have thus become a major site of contestation throughout Africa.

In most of Africa land use regulations and planning frameworks have been an ideological tool for maintaining unequal distribution of land and inequitable security of tenure. The regulation of land use, usually rationalised on the basis of the need to protect legitimate public interests, is often unevenly applied to different tenure systems and through this to different classes of landowners and land use systems. In many cases the imposition of land use regulations is intended to protect the interests of emerging agrarian capitalists rather than the public or national interest. In other cases the regulations may in theory protect the public interest but, because of unequal land distribution, their impact is to deny the excluded peasantry their legitimate right to state support. The question is whether these new generations of land use policies and regulations promote efficiency in the utilisation of land and labour resources and thus improve national development in general. The persistence of under-utilisation, low land productivity and external land use orientation suggests that economic policies have been an obstacle to agricultural transformation, while promoting new forms of control over land ownership and the production content for the benefit of narrow interests.

\section{Land reforms in Africa: Redistribution versus tenure reform}

African redistributive land reforms would be expected to involve restoring lands that are physically controlled by large landholders through the resettlement of displaced peasants and alienated semi-proletarians and the enlargement of peasant land areas using repossessed contiguous lands. Securing land rights of the poor mainly by re-allocating them the 'title' to independently hold the landholding and/or by upgrading the tenure conditions under which lands are rented is also relevant in parts of Africa where land rent and sharecropping have emerged, especially in West Africa. Redistributive land reforms are critical in large parts of southern, eastern and northern Africa, where highly unequal landholdings have produced landlessness and land shortages. However limited redistributive land reforms had been attempted there since the late 1950s, while since the 1980s gradualistic market-based land reforms have been initiated in southern Africa. Land reform was only 'radicalized' recently in Zimbabwe. The need for redistributive land reforms would also be expected in other African countries where localised and regional enclaves of land concentration have emerged through gradual and piecemeal expropriation by the colonial and post-independence state and private actors.

Some of the stated objectives of land redistribution in Africa include:

- decongesting overpopulated areas 
- expanding the base of productive agriculture

- rehabilitating people displaced by war

- resettling squatters, the destitute and the landless

- promoting more equitable distribution of agricultural land

- de-racialising or expanding indigenous commercial agriculture.

These objectives are underpinned by the aim of addressing historical injustices of colonial land expropriation and to assert the right of access by 'indigenes'. Land redistribution has tended to be severely circumscribed by market-oriented approaches to land acquisition and legal challenges to land expropriation mechanisms by large land owners, while the negotiated voluntary transfer of land has not occurred on a significant scale (Moyo 2004). In East Africa redistributive reforms were mainly pursued in Ethiopia and Kenya.

Redistributive land reform processes in Africa span the 40-year history of national liberation, but the experiences vary according to the land questions faced in each country. Whereas different socioeconomic and political specificities determine the nature of land reforms carried out, the gradual shifts in the nature of national liberation struggles among the countries since the 1960s reflect changing ideological and political mobilisation of the social forces engaged in resistance to imperial rule and changing land reform strategies. For example land reform experiences in southern Africa exhibit a changing divide between radical nationalist-cum-socialist redistributive land reforms and liberal approaches (Moyo 2004). Where national liberation was decisively concluded, as in Mozambique and Angola, the land distribution question appears to have been broadly resolved, although new sites of localised land concentration have emerged. Where liberation was only partially concluded, as in the main settler territories of Zimbabwe, Namibia and South Africa, negotiated settlements left both the national question and the land question relatively unresolved. In particular the racial dimensions of the national question were not adequately addressed, as structures of wealth, income and land distribution remained intact and protected by liberal democratic constitutions and market principles.

More radical land reforms entailed the nationalisation of colonial, foreign and settler landholdings, as in Zambia during the early 1970s and in Mozambique and Angola from the mid-1970s. Zambia and Tanzania pursued 'socialist' land and agrarian reforms based on state marketing systems and the reorganisation of land settlement and use (villagisation and rural development in Tanzania and resettlement and integrated rural development in Zambia), while Mozambique pursued land nationalisation with more intensive attempts at socialist transformation using state and cooperative farms. 
Angola, which started-off mired in civil war, did not pursue further significant land reform after land nationalisation. Civil war in the lusophone territories, fuelled by their relative international isolation and by South African destabilisation contained radical agrarian reforms there, and post-conflict land tenure reforms have re-introduced some land concentration.

In contrast more liberal strategies of land reform were adopted in the colonial 'protectorates', which mostly experienced indirect colonial rule accompanied by minor degrees of white settlerism alongside cheap migrant labour systems (Botswana, Lesotho, Malawi and Swaziland, Lesotho). Here land reform involved a limited degree of expropriation of lands accompanied by market-related compensation with some colonial finance, as was the case in Swaziland and Botswana. The expropriated land was 'indigenised' as large farms, with limited foreign and white minority large-scale land ownership and estate farming remaining alongside the emergence of state farms and resilient peasant and pastoral agrarian structures. Liberal approaches to land reform consisted mainly of limited market-led land redistribution efforts and attempts to modernise peasant agriculture within a contradictory context of imbalanced public resource allocations focusing on the large-scale indigenised and state capitalist farming sub-sector, and agricultural export markets.

Zimbabwe and Namibia since the 1980s used the liberal state-centred but market-based approach to land transfers. Land was acquired by the state for redistribution on a willing-seller-willing-buyer basis, meaning that land identification and supply was market-driven. The governments identified the demand for land and, where possible, matched it with this private supply. These programmes were slow in redistributing land, except during the very early years in Zimbabwe, when the approach was accompanied by extensive land occupations on abandoned white lands. The use of compulsory land acquisition by the state, with or without compensation for land and improvements, was pursued mainly in the early independence periods, when expropriations with varying levels of compensation were adopted in Zambia and, since the 1990s, mainly in Zimbabwe. This approach involves direct intervention by government in the identification and acquisition of land.

Another liberal approach to land redistribution, tried to a limited degree in both South Africa and Zimbabwe, is the 'market-assisted' approach espoused by the World Bank. This approach is meant to be led by beneficiaries, with support from the state, private sector and NGOs within a market framework. Very little land has been redistributed through this approach so far, mainly in South Africa. This approach was implemented in Malawi in 2005, using a World Bank loan in the context of the usual macroeconomic policy conditions. Finally a 'community-led self-provisioning' strategy (Moyo 
2000) has been followed in Zimbabwe, mainly in the form of 'illegal' land occupations by potential beneficiaries. This approach has tended to be either state-facilitated and formalised or repressed by the state at various points in time (Moyo 1995).

Despite all these approaches relatively little progress has been achieved in the implementation of redistributive land reform in Africa, while greater effort has been placed on land tenurial and land use regulatory reforms. However more progressive land tenure reforms to counter the general tenure insecurities and land grabbing processes facilitated by regressive state-led land tenure reforms are necessary. Current resistance to land marketisation and 'individualization' schemes, as well as to the manipulative reform of land administration structures through the adaptation of customary tenure procedures and institutions and new efforts to decentralise and reform land governance systems, is a response to the contradictions that confront progressive land tenure reform. However land tenure reform in Africa also requires institutional reforms that can defend the poor against potential land losses as well as accommodate those excluded (women, minorities, settlers) from increasingly scarce arable lands. Such tenure reforms would also need to be able to prevent and resolve conflicts over competing claims to land rights and ensure the fair administration of land rights and land use regulations. Whether the land tenure reforms required would include the ability to transact (rent and sell) and mortgage peasant lands, especially in the absence of measures to prevent land alienation and concentration, is as politically contentious as its feasibility is questionable.

The role of the African state in promoting equitable access to and control of land through tenure reforms has had the opposite effect of promoting increased land concentration. Existing African legal frameworks and institutions for managing land allocation and land use or dispute resolution tend to protect the interests of those with disproportionately larger land rights, including property rights derived from past expropriation, rather than the interests of the victims of these inequities. Indeed the literature on Africa's land tenure identifies weak land administration systems as the main issue of concern (Quan 2000; Adams 2000). Land administration reforms tend to be proposed within a neo-liberal conception of good governance, focusing on the decentralisation and democratisation of land institutions, enhancement of land administrative efficiency, broad-based representativity of local structures of land control and civil society participation in land administration, within a framework of introducing formal and statutory law into land management systems. The main purpose of these proposed reforms is to develop 'secure land tenure' regimes - and implicitly to make the institutions benign to market processes. 
However, most African governments have yet to allocate the resources and build the capacities required to create these new systems of land administration (Palmer 2002). Decentralised land reform implementation processes have failed to take off, largely due to a lack of both financial resources and technical capacities, as well as the lack of political will. Yet there is no doubt that African land management institutions pose vexing problems and that these constitute an important aspect of the land question. The institutional frameworks for land administration are exceedingly complex and fractured (Shivji 1998; Palmer 2002). There are numerous competing agencies involved in land administration, including line ministries and central government departments, large parastatals, urban and rural local authorities and traditional leaders (Moyo 1995). The responsibilities of these different agencies in different aspects of land administration within the different land tenure areas overlap and create confusion and conflict among the various players, thus posing difficulties for the creation of integrated and comprehensive land administration processes (Shivji 1998).

A truly democratic approach to land administrative reform would require that the basic principles of democracy - equity, efficiency, accountability, transparency, legitimacy, and participation - be the guiding criteria for resolution of land administrative problems (Shivji et al. 1998). The concentration of administrative powers over land and natural resources in national authorities is the main obstacle. Popular demands for transparency reflect concerns over corrupt land and resource allocations, especially the tendency for state officials and political leaders to dominate licenses, leases and concessions. The land administration institutions also tend to be inaccessible and unrepresentative of local interests (Shivji et al. 1998).

In many countries land administration remains highly centralised and unrepresentative, while the institutions that adjudicate land issues at the local level are widely dispersed and weak at best (Shivji et al. 1998), a situation which tends to perpetuate centralised powers over customary land tenure regimes. Furthermore, as Amanor (2003) argues, there are limited channels for addressing land grievances and demands for land tenure reform. Rural popular organisations tend to be weak and dominated by lineage elders, a framework that has been reinforced by the state to prevent rural demands from being placed in a broader horizon beyond the community (Amanor 2003). Thus, since the territorial distribution of local 'traditional' authorities are generally based upon lineage/clan social structures with particular ethnic identities, land conflicts have tended to assume an explicit or implicit 'ethnic' character. Colonial administrations in Africa universally created administrative and political districts around 'tribal' chiefdoms, which in many cases imposed regional centres of ethnically-based chiefly authority over groups that had in 
fact been autonomous, thus creating conflicted land administration structures. Moreover the preoccupation with formal land tenure reforms has tended to mean that most official land policies neglect redistributive aspects such as improving access to land, water, nature parks, forests and woodland resources by the poor, while efforts to improve environmental security, alleviate poverty and improve land and labour productivity tend to focus on small-scale palliatives in marginalised peasant lands.

\section{Land movements and struggles in Africa}

Because of the centrality of access to land in the livelihoods of the majority of Africans, social demand for land reforms - expressed in different forms depending on the nature of social forces which articulate them - have grown. Indeed renewed debates about the nature of African peasantries and their future suggest that mainstream intellectual discourses on the struggles for land in Africa have tended to underestimate the political significance of the land question in discussions on an alternative development path for Africa. In Africa numerous civil society groupings associated with the current renaissance of peasant organisations are predominantly middle-class, with strong international aid linkages. These structures tend to neglect radical land reform strategies and reproduce formal grassroots peasant organisations as appendages of middle-class development and democratisation agendas. $\mathrm{Ru}-$ ral operations of civil society in Africa within a neo-liberal framework have been characterised by demands for funds for small-project 'development' aimed at a few selected beneficiaries (Moyo 2002), leaving a political and social vacuum in the leadership of the land reform agenda (Moyo 2001). Membership of formal rural or farmers political unions tends to be widely differentiated, with leaderships dominated by an elite group of farmers whose demands are for larger portions of freehold land (Moyo 1995). These organisations, like their counterpart community-based organisations which form mainly under the social control of lineage hierarchies, far from representing the majoritarian peasant demand for redistributive land reforms, have been co-opted into neo-liberal land tenure reformism. The majoritarian land interests are more often reflected in informal movements representing a variety of social forces, including those that pursue land occupations, resource poaching and other forms of 'sabotage'.

Land occupation movements such as those in rural and urban Zimbabwe before and after the country's independence represent an unofficial or underground social pressure used to force land redistribution onto the policy agenda (Moyo 2001). The 2000-2001 occupations in Zimbabwe marked the climax of a longer, less public and more dispersed struggle over land in that country, which intensified under adverse economic conditions that were exacerbated 
by the onset of liberal economic and political reform. The dynamics of land reform in this and other contexts are complex and can best be understood in political terms, that is, in terms of a protracted struggle by peasants, poor urban workers and other groups for access to land and in terms of the reaction to this struggle by the dominant landholding class and by the state (Petras and Veltmeyer 2001). Land occupations thus reflect a tactic of class struggle and direct collective action.

Land movements are differentiated and adopt different strategies whose tactics may contradict some progressive struggles on issues such as democratisation. In Africa the tactics of land occupation for example have not been nationally comprehensive, and the absence of a political and institutional infrastructure for widespread mobilisation of the African peasantry has been a major bottleneck, along with neo-liberal ideologies that define the strategies of dominant civil society organisations. These ideologies inform us more on how farmers' associations can be directed to advocate agendas grounded in neo-liberal policies, on agricultural modernisation through increased exports and improved land use practices, on the short-term financial and environmental utility of land use change for global markets and ecological stabilisation.

Yet land movements and struggles are numerous, albeit isolated and scattered, even if many are incipient and not formally organised. High-profile and low-profile conflicts of both a spontaneous and engineered genre abound (Moyo 2001). Some land movements resist the dominant logic of capitalist development in rural areas and in particular struggle to retain control over land (Lumumba 2003). In general even formal farmers' organisations and unions that collaborate with the state are differentiated in their political intent and domestic policy demands, given their relationship to capital, statedriven land processes and external social forces. Contemporary African rural movements, especially those that are organised, including those that are in the process of organising, and that have a progressive agrarian reform agenda, have proliferated over the last two decades but have not in most cases become the nuclei of oppositional politics within their respective states. Nor have they pushed radical land and agrarian reform to the centre of the development agenda. This weakness or vacuum arises because their social base entails a rural-urban mix of small cultivators and proletarians, including the urban retrenched and unemployed, and because their leadership remains dominated by middle-class urban elites. Their tactics of direct action, using mainly land occupations and resource poaching in private and public lands, are overwhelmed by state repression and the welfarist projects of the NGO sector. 
For all their differences in tactics, strategies and results, the Zimbabwe war-veteran-led movements has been among movements that have laid claim on the most demanding of internationalisms. That the Zimbabwe war veterans movement did not capture the imagination of the left worldwide has less to do with the violence that was associated with it (which was in fact far less than in other political convulsions in Africa, Asia and Latin America that the left has supported) and more to do with the 'civilised' post-national and antistate norms of the anti-globalisation movement. Even the Landless People's Movement (LPM) in South Africa felt the contradictions of the situation, defending the land occupations in public fora but without going so far as to produce an official position.

Rural land movements have tended to be relegated to informal politics, while giving prominence to more organised middle-class civic groups and policy organisations that typically advocate market-based methods of land reform and liberal civic and political rights issues. Yet most civil society organisations, which are generally one-issue oriented in their advocacy, have tended to focus on proceduralist (redistributionist or governance) perspectives on social and economic change rather than on the structural issues required to address development challenges. Over the years the formal demand for radical land reform has tended to be submerged, especially in recent struggles for democratisation within a neo-liberal framework. Civil society discourses on land reform, therefore, tend to focus on law and governance issues, offering a critique of state-led methods of land acquisition without offering alternatives to land market acquisition and without mobilising an agrarian reform agenda focused on an alternative development agenda.

In general, demands for radical land and agrarian reform in Africa was led under colonial rule by the liberation movements and in the 1970s was pursued by means of armed struggle. In the independence period civil society land advocacy has been constrained by predominantly middle-class, social-welfarist and neo-liberal values, which are in turn dependent on international aid. Radical land reform continues to be demanded mainly by former liberation movements, war veterans' associations, the scattered efforts of traditional leaders and spirit mediums and a few emerging but narrowly based 'leftist' civil society organisations. As we have seen in South Africa, small left-leaning political parties and NGO groupings have supported the formation of a significant Landless People's Movement (LPM) that demands extensive land reform. However the contradictions between the mainly middleclass intellectual leadership of the landless peoples' structures and the trans-class and nationalist nature of the interests in land have become evident in the slow maturation of a nationwide radical land reform advocacy agenda. Nevertheless the LPM's demand for land redistribution using an explicit threat 
to boycott the ANC in elections has had the effect of bringing greater urgency to the government's land reform initiatives.

Indigenisation or affirmative action lobbies, seeking the construction of a broader agrarian capitalist class, some with ethno-regional and gender foci, have on the other hand re-focused the land reform agenda towards the deracialisation of the ownership base of commercial farmland in settler Africa and of a bi-modal large-small farmer agrarian structure. Thus a dual but essentially nationalist approach to land reform advocacy by aspirant large farmers and poor peasants now dominates the formal or official land reform agenda in Africa. This has shifted policy discourse on the criteria for access to land, refocusing the redistribution vision from the 'landless' and 'insecure' towards the 'capable' and 'efficient' indigenous agrarian capitalists, within the terms of the neo-liberal global development paradigm and using regional mobilisations.

In Botswana, some civil society land reform advocacy tends to be mobilised within a social and human rights framework of defending the land rights of 'indigenous' ethnic and marginalised minority groups, particularly the Basarwa. Increasingly the land struggles in Botswana involve ethnic minorities challenging the dominant paradigm of nation building that has been constructed through the diffusion of the values of the majority culture of the dominant Tswana groups. The Basarwa, often referred to as 'remote area dwellers', have historically been a servile underclass exploited by dominant Tswana groups as cattle herders and labourers (Molomo 2003). Removed from the major urban centres and enjoying limited government-assisted rural development and infrastructural facilities, they were recently moved out of the large Central Kalahari Game Reserve (CKGR) in a manner that subverted their land rights and subsistence livelihoods in order to expand the national tourist industry. Ethno-regional land movements are also increasingly seeking to attract state attention to land reform issues in their districts of origin. The land movements of the San in South Africa, Namibia and Botswana demand restoration of their land. Land struggles in Botswana involve ethnic minorities and NGOs challenging the dominant paradigm of the nation-state and demanding the reversal of Basarwa land alienation and social disruption. A trans-national land and social rights movement of the San ethnic formations in South Africa, Botswana and Namibia has also emerged with the support of NGOs from these and Western countries. Similarly pastoralist movements have emerged in East Africa.

With a few exceptions, such as the Land Campaign in Mozambique, which succeeded in making rural communities aware of their new rights under the law and how to go about legally establishing them (Negrao 1999), most of the new national land policies that result from NGO lobbying reflect 
mainstream interests. The common approach used to guide such interests includes expert panels, task forces, investigating teams or comprehensive commissions of inquiry that involve 'consultation' processes and reports that often provide material for the state's land policy decisions (Moyo 2004). Thus, for example, civil society advocacy has sought to unravel the landholdings of agrarian capitalists in Kenya, but their demands for radical redistribution have been muted. In Zimbabwe, on the other hand, recent rural land occupations reflect a diverse range of social forces including the rural landless, former refugees, war veterans, the rural poor, the youth, former commercial farm workers, women's groups, the urban poor and the black elite (Moyo 2004). While social movements that demand land reforms cannot be idealised, various progressive and retrogressive struggles for land reform suggest that their importance cannot be underestimated. The re-emergence of radical land reform in Zimbabwe since the mid-1990s, which coincided with the demise of its structural adjustment programme, marked an important shift in the political and economic relations between the peasantry and the state vis-à-vis urban constituencies.

\section{Conclusions}

The African state has neither promoted equitable access to land through redistributive reforms nor progressive land tenure reforms. Instead land concentration has increased. This is because existing legal frameworks and institutions for managing land reform tend to protect the interests of those with disproportionately larger land rights, including property rights derived from colonial expropriation, rather than expanding the productive capacities of the poor. African customary law and customary land rights have been manipulated to advance land concentration throughout the continent, including in those countries where large portions of the land were alienated under private property tenure regimes.

The fundamental issue is whether the strategies of emerging African land movements have the potential to influence radical land reform in the classical and historical sense of addressing the agrarian question. Examining this issue requires a structural rather than an eclectic analysis of Africa's agrarian questions, including the social and class interests and strategies of emerging social movements (Rahmato 1991; Veltmeyer 1997; Moyo 2003) and the emergence of an alternative African development vision unfettered by neoliberalism. Resolving Africa's land questions is critical to addressing the failed agrarian transitions and designing alternative development trajectories. This challenge underlies the national question in Africa today and calls for more introverted development strategies based on new international and regime linkages. 


\section{Notes}

1. 'Non-capitalist' phenomena were noted by classical theorists: Marx (1976: ch.13), noted the trafficking of children in England as a function of industrialisation and Lenin (1964: 204-206) the persistence of a quasi-feudal labour service in Russia) reflecting the propensity of capitalism to re-create such phenomena in the longer term (Yeros 2002a).

2. For details of the arguments here see forthcoming CODESRIA Greenbook, Moyo, 2008, African Land Questions, Agrarian Transitions and the State: Contradictions of Neo-liberal Land Reforms, Dakar: CODESRIA.

\section{References}

Adams, M., 2000, Breaking Ground: Development Aid for Land Reform, London: Overseas Development Institute.

Amanor, K., 2003, Land and Sustainable Development in West Africa, Harare: Africa Institute for Agrarian Studies.

Amin, S., 1972, Neocolonialism in West Africa, Hammondsworth: Penguin.

Arrighi, G., 1973, 'International Corporations, Labour Aristocracies, and Economic Development in Tropical Africa', in G. Arrighi, and J. Saul, eds., Essays on the Political Economy of Africa, New York: Monthly Review Press.

Bernstein, H., 2005, 'Rural Land and Land Conflicts in Sub-Saharan Africa', in S. Moyo and P. Yeros, eds., Reclaiming the Land: The Resurgence of Rural Movements in Africa, Asia and Latin America. London: Zed Books.

Bruce, J. W., 1996, Country Profiles of Land Tenure, Madison: Africa Land Tenure Center, University of Winsconsin.

Bryceson, D., 2000, 'African Peasants Centrality and Marginality: Rural Labour Transformations', in D. Bryceson, C. Kay and J. Mooji, eds., Disappearing Peasantries?: Rural Labour in Africa, Asia and Latin America, London: ITDG Publishing.

Bryceson, D., Kay, C. and Mooji, J., eds., 2000, Disappearing Peasantries?: Rural Labour in Africa, Asia and Latin America, London: ITDG Publishing.

Cabral, A., 1979, Unity and Struggle, New York: Monthly Review Press.

De Soto, H., 2000, The Mystery of Capital: Why Capitalism Triumphs in the West and Fails Everywhere Else. London: Black Swan.

Delville, P.L., 1999, Harmonising Formal Law and Customary Land Rights in French-Speaking West Africa, London: International Institute for Environment and Development.

Delville P. L., Toulmin, C., Colin, J-P., and Chauveau, J-P., 2002, Negotiating Access to Land in West Africa: A Synthesis of Findings from Research on Derived Rights Land, London: International Institute for Environment and Development.

Eicher, M. and Rukuni, C. K., 1995, 'Zimbabwe's Agricultural Revolution: Lessons for Southern Africa', in M. Rukuni and C.K. Eicher, eds., Zimbabwe's Agricultural Revolution, Harare. University of Zimbabwe Press. 
EU, 2004, Guidelines for Support to Land Design and Land Reform Processes in Developing Countries. Final Draft for Consultation. Brussels: EU Task Force on Land Tenure.

Fanon, F., 1961, The Wretched of the Earth, London: Penguin Books.

Flintan, F. and Tamrat, I., 2002, 'Spilling Blood over Water? The Case of Ethiopia', in J. Lind and K. Sturman, eds., Scarcity and Surfeit: The Ecology of Africa's Conflicts. Pretoria: ISS, pp. 243-319.

Geschiere, P. and Nyamnjoh, F., 2000, 'Capitalism and Autochthony: The Seesaw of Mobility and Belonging' in J. Comaroff and J. L. Comaroff, eds., Millennial Capitalism and the Culture of Neo-liberalism. Durham, NC: Duke University Press., pp. 423-452.

Ghai, D. and Radwan S., 1983, Agrarian Policies and Rural Poverty in Africa, Geneva: International Labour Organisation.

Gibbon, P. and Neocosmos, M. 1985, 'Some Problems in the Political Economy of "African Socialism"', in H. Bernstein and B. Campbell, eds., Contradictions of Accumulation in Africa, London: Sage.

Lumumba, O. and Kanyinga, K., 2003, 'The Land Question and Sustainable Development in Kenya'. Draft paper for the Regional and World Summit on Sustainable Development (WSSD) Dialogue Initiative: An African Perspective on Land and Sustainable Development.

Lastarria-Cornhiel, S., 2002, 'Concepts of Property Rights and Citizenship: Market Economy, Customary Tenure, and Gender', presentation for Conference on Conflicts over Land and Water in Africa: Questions of Citizenship and Identity, Centre for Development Research Copenhagen, 28-29 November 2002.

Lipton, M., 1976, Why Poor People Stay Poor: A Study of Urban Bias in World Development, Cambridge, MA: Harvard University Press.

Mafeje, A., 1997, 'The Agrarian Question in Southern Africa and Accumulation from Below', SAPEM, Vol. 10, No. 5.

Mafeje, A., 1999, 'Imperatives and Options for Agricultural Development in Africa: Peasant or Capitalist Revolution?', unpublished essay.

Mafeje, A. 2003, 'The Agrarian question, Access to Land and Peasant Responses in Sub-Saharan Africa', UNRISD Programme papers on Civil Society and Social Movements.

Mamdani, M., 1996, Citizens and Subjects: Contemporary Africa and the Legacy of Late Colonialism, Princetown, NJ: Princeton University Press.

Mamdani, M., 2001, When Victims Become Killers: Colonialism, Nativism, and the Genocide in Rwanda. Princetown, NJ: Princeton University Press.

Molomo, M.G., 2003, 'The Land Question and Sustainable Development in Botswana', draft paper for the World Summit on Sustainable Development (WSSD) Dialogue Initiative: An African Perspective on Land and Sustainable Development.

Moyo, S., 1995, The Land Question in Zimbabwe, Harare: SAPES Books.

Moyo, S., 2000, Land Reform Under Structural Adjustment in Zimbabwe: Land Use Change in Mashonaland Provinces, Uppsala: Nordiska Afrika Institutet. 
Moyo, S., 2001, 'The Land Occupation Movement and Democratization in Zimbabwe: Contradictions of Neo-liberalism', Millennium Journal of International Studies, Vol. 30, No. 2, pp. 311-330.

Moyo, S., 2002, 'Peasant Organisations and Rural Civil Society in Africa: An Introduction', in S. Moyo and B. Romdhane, eds., Peasant Organisations and Democratisation in Africa, Dakar: CODESRIA.

Moyo, S., 2003, 'The Interaction of Market and Compulsory Land Acquisition Processes with Social Action in Zimbabwe's Land Reform', in I. Mandaza and D. Nabudere, eds., Pan Africanism and Integration in Africa, Harare: Sapes Books.

Moyo, S., 2004, 'Land, Food Security and Sustainable Development in Africa', paper prepared for the United Nations Economic Commission for Africa (UNECA), Sustainable Development Division, Ethiopia.

Moyo, S., 2005, 'The Politics of Land Distribution and Race Relations in Southern Africa', in Y. Bangura and R. Stavenhagen, eds., Racism and Public Policy, London: Palgrave Press.

Moyo, S. and Yeros, P., 2005a, 'Land Occupations and Land Reform in Zimbabwe: Towards the National Democratic Revolution', in S. Moyo and P. Yeros, eds., Reclaiming the Land: The Resurgence of Rural Movements in Africa, Asia and Latin America, London: Zed Books.

Moyo, S. and Yeros, P., 2005b, 'Resurgence of Social Movements', S. Moyo and P. Yeros, eds., Reclaiming the Land: The Resurgence of Rural Movements in Africa, Asia and Latin America, London: Zed Books.

Moyo, S., 2008, African Land Questions, Agrarian Transitions and the State: Contradictions of Neo-liberal Land Reforms, Dakar: CODESRIA.

Murombedzi, J., 1999, 'Land Expropriation, Communal Tenure and Common Property Resource Management in Southern Africa', The Common Property Resources Digest, October 1999.

Negrao, J., 1999, 'The Mozambican Land Campaign, 1997-1999', paper presented at the Workshop on the Associative Movement, Maputo, 14 December' (http: //www.Oxfam.org.uk/landrights), 15 November 2006.

Palmer, R., 2000, 'The Struggles Continue: Evolving Land Policy and Tenure Reforms in Africa: Recent Policy and Implementation Process' in C. Toulmin, C. and J. Quan, eds., Evolving Land Rights, Tenure and Policy in Sub-Saharan Africa, London: IIED.

Palmer, R., 2002, 'A Guide to, and Some Comments on, The World Bank's Policy Research Report (PRR), Land Policy for Pro-Poor Growth and Development', in Ethnic Clashes in Kenya, Nairobi: Peacenet-Kenya 2001 (www.peacenetKenya.org/projects/ethniclashes.htm) 15 November, 2006.

Petras, J. and Veltmeyer, H., 2001, 'Are Latin American Peasant Movements Still a Force for Change? Some New Paradigms Revisited' Journal of Peasant Studies, Vol. 28, No. 2.

Petras, J., 1997, 'MST and Latin America: The Revival of the Peasantry as a Revolutionary Force', Canadian Dimension, Vol, 31, No. 3. 
Platteau, J. P., 1996, 'The Evolutionary Theory of Land Rights as Applied to SubSaharan Africa: A Critical Assessment', Development and Change, Vol 27, No. 1, pp. 29-86.

Quan, J., 2000, 'Land Tenure, Economic Growth and Poverty in Sub-Saharan Africa', in C. Toulmin and J. Quan, 2000, Evolving Land Rights, Tenure and Policy in Sub-Saharan Africa, London: IIED, pp. 31-49.

Rahmato, D., 1991, 'Peasant Organisations in Africa: Constraints and Potentials', CODESRIA Working Paper 1/91, Dakar: CODESRIA.

Sender, J. and Johnston, D., 2004, 'Searching for a Weapon of Mass Production in Rural Africa: Unconvincing Arguments for Land Reform', Journal of Agrarian Change, Vol. 4, No. 1/2, pp. 142-164.

Shivji, I., 1998, Not Yet Democracy: Reforming Land Tenure in Tanzania. Dar es Salaam: International Institute for Environmental and Development (Drylands Programme), HAKIARDHI (Land Rights Research and Resources Institute), and the Faculty of Law, University of Tanzania.

Shivji, I. G., Moyo, S., Ncube, W. and Gunby, D., 1998. 'Draft National Land Policy for the Government of Zimbabwe', discussion paper, Harare: FAO and Ministry of Lands and Agriculture.

Submarian, J., 1996, 'Eritrea Country Profile,' in J. W. Bruce, ed., Country Profiles of Land Tenure, Madison, WI: Africa Land Tenure Center, University of Wisconsin, pp. 164-168.

Tsikata, D., 1991, Securing Women's Interests within Land Tenure Reforms: Recent Debates in Tanzania. Journal of Agrarian Change, Vol. 3, No. 1/2, pp. 149-183.

Veltmeyer, H., 1997, 'New Social Movements in Latin America: The Dynamics of Class and Identity', Journal of Peasant Studies, Vol. 25, No. 1.

World Bank, 2002, Land Policy for Pro-Poor Growth and Development. Washington, DC: World Bank.

Yeros, P., 2002a, 'Zimbabwe and the Dilemmas of the Left', Historical Materialism, Vol. 10, No. 2, pp. 3-15.

Yeros, P., 2002b, 'The Political Economy of Civilisation: Peasant-Workers in Zimbabwe and the Neocolonial World', PhD dissertation, London School of Economics. 